\title{
The Effects of Combination of Range Motion and Deep Breathing Exercise on Pain in Post-Orthopedic Surgery Patients
}

\author{
Hery Sasongko'), Tintin Sukartini²), Erna Dwi Wahyuni²), \\ Made Mahaguna Putra ${ }^{3)}$ \\ ${ }^{1)}$ Masters Program in Nursing, Universitas Airlangga \\ 2)Faculty of Nursing, Universitas Airlangga \\ 3)School of Health Sciences Buleleng, Bali, Indonesia
}

\begin{abstract}
Background: Broken bones can cause soft tissue edema, bleeding in the muscles and joints, tendon rupture, damage to nerve tissue and damage to the vasculer and surgery are ways that are carried out to restore the movement function of extremitas and the impact that occurs due to these actions is pain. Acute pain is still found in postoperative non-pathological fracture patients who have received analgesic ketorolac.
\end{abstract}

Subjects and Method: This was a quasy experiment study conducted at Dr. Soetomo Hospital, Surabaya, East Java. A sample of 46 patients post orthopedic surgery was selected for study by purposive sampling. The dependent variable was pain. The independent variables were range of motion and deep breathing exercises. Pain was measured by visual analog scale (VAS). The data were analyzed by t-test.

Results: After treatment, pain level in the intervention group (mean $=2.43$; $\mathrm{SD}=1.41$ ) was lower than the control group (mean $=3.48 ; \mathrm{SD}=1.38$ ) with $\mathrm{p}=0.014$.

Discussion: Combination of range of motion and deep breathing relaxation therapy effective to reduce pain among post orthopedic surgery patients.

\section{Correspondence:}

Hery Sasongko. Masters Program in Nursing, Universitas Airlangga. Email: herysasongko.ners@gmail.com.

\section{BACKGROUND}

$\overline{\text { Fracture is a condition that causes disrup- }}$ tion of continuity of bone and cartilage tissue caused by force (Smeltzer and Bare, 2013; American Academy Orthopedic Surgeons, 2013). Broken bones can cause soft tissue edema, bleeding in muscles and joints, rupture tendons, nerve tissue damage and vasculary damage and surgery are ways that are carried out to restore the motion function of extremity and the effects that occur due to these actions are pain, acute pain is still found in patients after orthopedic surgery who have received analgesic ketorolac.

The interview with the head of the room at Dr. Soetomo Hospital, Surabaya, East Java, stated that some of the patients requested to be given analgesia after the first 3 hours of administration. According to Chelly (2003) this is because all surgery in orthopedic units will result in the intensity and the duration of acute pain that is different from other system units due to the degree of damage that starts from superficial, soft tissue, bone exposed, blood vessels to nerves. The demand for analgesics to reduce pain in patients is in line with the high risk of drug side effects such as pruritus, nausea and vomiting, dizziness, dry mouth, feelings of weakness, visual disturbances, palpitations, sedation, confused, agitation, urine retention to constipation (Schumacher, 2007). Recovery process will cause a chemical reaction in the body that causes patients to feel pain (Ani, 2010). Early warning systems accord- 
ing to the Royal College of Physicians in 2012 included six points, i.e. breathing, oxygen saturation, temperature, blood pressure, heart rate and level of consciousness (National Clinical Effectiveness Committee, 2013). Preliminary study by Ilmiasih (2015) showed that postoperative pain can affect hemodynamic stability, can reduce immunity, thus disrupting the healing process.

Preliminary study conducted at Prof. Dr.R.D. Kandou hospital, Manado, Indonesia, to 30 patients performed 2 days after fracture surgery shows that out of 15 patients who were not given intervention, there were mild pain as many as 6 patients (40\%), moderate pain as many as people (26.7\%), severe pain as many as 3 people (20\% ) and very severe pain in 2 people (13.3\%). After intervention in deep breathing relaxation techniques, there were 2 patients who said there was no pain, no patients said moderate pain and very severe pain, there was an effect on the intervention of deep breathing towards the patient's pain response. The study was supported by Nurdin et al. (2013) in the same place, namely 11 people (55\%) with severe pain intensity and severely reduced to 10 people with moderate pain intensity and 1 person without pain. 8 people (40\%) has the intensity of pain reduced to mild pain, mild pain 1 person (5\%) which became painless.

According to the Indonesian Ministry of Health/Kemenkes RI (2015), among cases of fractures in Indonesia, fractures of the extremities have the highest prevalence among other fractures, which is around 46.2\%. The accident cases were 45,987 people with cases of limb fractures due to accidents, 19,629 people had femur fractures, 14,027 people had cruris fractures, 3,775 people had tibia fractures, 9702 people had fractures in small bones in the legs and 336 people had broken fibular bone. According to the results of Basic Health Reseacrh (RISKESDAS) the number of fractures in the Women's Development Institute in 2013 increased compared to the results in 2007.

The results of the survey and data collection from the annual report of the Orthopedic and Traumatology Department/ faculty of medicine, Universitas Airlangga/ Dr. Soetomo Hospital, Surabaya in 2017 show that those who were performed surgically in the emergency room operation room were 938 patients with 10 most diagnoses or $(32 \%)$ of the total surgery in the emergency room for upper extremity is 31 closed fracture of upper humerus patients, 28 upper end closed radius of upper fracture, while 29 lower extremity diagnoses are closed fracture shaft of tibia, while surgery in the operating room amounting to 1275 surgery integrated center building or (22\%) of the total surgeries from all surgical departments. Surgical diagnoses at the surgery integrated center building for upper extremity were 27 patients with closed fracture distal radius, 34 fractures of lower both ulna and radius, while lower extremity diagnoses were femur closed fracture as many as 151 patients, from the number of surgical procedures performed at the emergency room and surgery integrated center building operating room with fracture lower extremity diagnosis and upper extremity were obtained by 300 patients on average a month there were 23 patients who underwent surgical Open Reduction Fixation (ORIF) to restore motion function and reduce fracture pain.

Deep breathing exercise intervention has been carried out in hospitals as a relaxation technique to reduce pain intensity in all cases, because deep breathing exercise is a therapeutic pharmacology that 
supports pharmacological therapy in a simple, inexpensive, practical, and without side effects. detrimental (Potter and Perry, 2010). Deep breathing exercise (DBE) or deep breath therapy is often combined with other nonpharmacological therapies such as the combination of DBE and guide imagery, this study has not shown significant results in the process of reducing pain in patients with surgery (Lim et al., 2014). DBE and hypnosis therapy can be carried out by people who are trained and skilled in the field so that the effectiveness of postoperative bone patients is minimal (Lim et al., 2014).

The effect of the combination of DBE and range of motion (ROM) will increase comfort and reduce the intensity of postoperative pain in fractures. Mechanism in reducing pain with Range of Motion intervention in post orthopedic patients, namely sensory pain distraction which has an important role in reducing pain by eliminating the concentration of patients at the site of pain or surgery area, reducing activation of chemical mediators in the inflammatory process that increases pain response and minimize nerve pain transmission to the central nerve. Postoperative pain can cause stress which causes excessive release of catecholamine and steroid hormones. This stress-causing hormone can cause smooth muscle tension and vasoconstriction of blood vessels so that blood flow and oxygen will decrease. Decreased circulation of blood flow causes a disruption of the fulfillment of oxygen and nutrients to the tissue around the surgical site which results in a process of wound healing and the process of repairing the surrounding tissue is also disrupted.

The combination of ROM and DBE help reduce pain which can reduce stress hormones by increasing oxygen content and blood supply to the tissues. The combination of ROM and DBE intervention given to post orthopedic patients is very capable of being used to reduce pain, so the combination of ROM and DBE against pain and signs vital signs of patients after orthopedic surgery can be used as standard operational procedures in reducing pain in hospitals in non-pharmacology. This study aimed to analyze the effect of ROM and DBE on pain among patients after orthopedic surgery.

\section{SUBJECTS AND METHOD \\ 1. Study Design \\ This was a quasi experiment study con- ducted at Dr. Soetomo Hospital, Surabaya, East Java, Indonesia.}

\section{Samples}

A sample of 46 patients post orthopedic surgery was selected by purposive sampling. The inclusion criteria in the study were: 1$)$ Patients after elective and emergency surgery within 60 minutes, 2) Nonpathological fractures, 3) Patients with upper extremity fractures or lower extremities with mild to severe pain intensity, 4) Patients post ORIF surgery (Fixasi Internal Open Reduction) in upper or lower extremity fractures without other concomitant surgeries, 5) 21-50 years old, 6) Patients with GCS 456 during assessment and intervention, 7) New patient or first time surgery patient and not patient re -open surgery, 8) The type of analgesic given is ketorolac.

\section{Study Variables}

The dependent variable was pain. The independent variables were range of motion and deep breathing exercise.

\section{Study Intruments}

Pain levels are measured using the visual analog scale (VAS) (Smeltzer and Bare, 2001).

\section{Data Analysis}

The data were analyzed using paired $t$ test. 


\section{Research Ethics}

Research ethics were obtained from Research Ethics Committee Dr. Soetomo hospital, Surabaya, East Java, with a certificate number 0829 / KEPK / XII / 2018.

\section{RESULTS}

1. Univariate Analysis

Table 1 showed the frequency distribution of samples based on age, gender, and type of fracture.

Table 1. Frequency Distribution of Sample

\begin{tabular}{|c|c|c|c|c|c|}
\hline \multirow{2}{*}{ Variables } & \multicolumn{2}{|c|}{ Intervention Group } & \multicolumn{2}{|c|}{ Control Group } & \multirow[b]{2}{*}{$\mathbf{p}$} \\
\hline & $\mathbf{n}$ & $\%$ & $\mathbf{n}$ & $\%$ & \\
\hline \multicolumn{6}{|l|}{ Age } \\
\hline 17 - 40 years old & 23 & 51.1 & 22 & $48.9 \%$ & \multirow{3}{*}{0.342} \\
\hline 41 - 60 years old & o & 0 & 1 & 100 & \\
\hline \multicolumn{5}{|l|}{ Gender } & \\
\hline Male & 12 & 48 & 13 & 52 & \multirow[t]{2}{*}{0.606} \\
\hline Female & 11 & 52.4 & 10 & 47.6 & \\
\hline \multicolumn{6}{|l|}{ Type of Fracture } \\
\hline Upper Extrimity & 8 & 42.1 & 11 & 57.9 & \multirow[t]{2}{*}{0.154} \\
\hline Lower Extrimity & 15 & 55.6 & 12 & 44.4 & \\
\hline
\end{tabular}

Table 1 showed that the age groups in the intervention and control groups were mostly 17-40 years old, male gender, and had fractures in the lower extremities. Homogeneity, age $(\mathrm{p}=0.342)$, gender $(\mathrm{p}=$ o.606), and fracture $(\mathrm{p}=0.154)$ showed that the general characteristics of sample who participated in the study were homogeneous.

Table 2. Pain level of patients with orthopedic surgery before treatment

\begin{tabular}{lccc}
\hline Group & Mean & SD & p \\
\hline Intervention & 4.52 & 1.04 & 0.903 \\
Control & 4.48 & 1.16 & \\
\hline
\end{tabular}

Table 3. Pain level of patients with orthopedic surgery after treatment

\begin{tabular}{lccc}
\hline Groups & Mean & SD & p \\
\hline Intervention & 2.43 & 1.41 & 0.014 \\
Control & 3.48 & 1.38 & \\
\hline
\end{tabular}

Table 2 indicated the pain level of patients with orthopedic surgery before treatment. Table 2 showed that before the treatment was given, there was almost no difference in pain levels in the intervention group (mean $=4.52 ; \mathrm{SD}=1.04$ ) and the control group $($ mean $=4.48 ; \mathrm{SD}=1.16)$ with $\mathrm{p}=0.903$.

Table 3 showed the pain level of patients with orthopedic surgery after treatment. Table 3 showed that after being given motion range and depth breathing treatments, the pain level in the intervention group $($ mean $=2.43 ; \mathrm{SD}=1.41)$ was lower than the control group (mean $=3.48$; $\mathrm{SD}=1.38$ ) with $\mathrm{p}=0.014$.

\section{DISCUSSIONS}

The combination of range of motion and deep breathing exercise therapies for patients after orthopedic surgery in Table 2 showed different levels of pain. Both groups 
showed different mean pain levels, which were 3.48 (control group) and 2.43 (treatment group). Pain scores of samples in both groups had a maximum pain score of 6 . This was in accordance with the theory which stated that after orthopedic surgery, the patients had experienced acute pain at a severe level. Surgery in the orthopedic unit was able to deliver the intensity and duration of acute pain that were different compared to other care units. This was due to the degree of damage that injured from superficial, soft tissue, boned exposed, blood vessels and nerves (Royal College of Physicians, 2012).

The results of the study in table 1 showed that most of the study respondents were in the age range of young adults (97.8\%). This was in accordance with the theory which stated that pain was reported only if it has become a pathological state and has impaired function and this was often done by adults (Flor et al., 2011). Table 1 showed that the majority of samples were male. The National Health Survey reported that cases of fractures occurred more in men than women (Novita, 2012). The fact showed that the prevalence of traffic accidents and workplace accidents was more common in men than in women. If it was associated with the incidence of postoperative orthopedic pain with the characteristics of acute and severe pain, then this was not in accordance with the theory which stated that women focused more on pain so that the pain sensation was higher in women because clients who focused their attention on pain can affect pain perception (Smeltzer et al., 2013).

The analysis showed that the type of fracture found at the study site was fracture that occurred in the lower extremity of $52.2 \%$ of all cases, this was in accordance with the study conducted by Noorisa et al. (2017) which stated that the most common type of femoral fracture has closed wounds (71\%) and was located in the thigh bone column (46\%). The most common cases of femoral fractures occurred in men of productive age due to traffic accident injuries.

Pain in patients after orthopedic surgery was acute pain, which was caused by tissue damage that occurred not only due to surgical incisions but also previous trauma which was an indication of orthopedic fracture operations (Smeltzer and Bare, 2012). Nurses have a role to deal with pain, pain response and side effects from the administration of medication therapy pain relief. It was one of the efforts in providing comprehensive nursing care services. Pain management was a collaboration of all service providers for the benefit of patients (Smeltzer and Bare, 2012)

An individual who experienced pain with the same type over and over again but the pain was successfully eliminated, it would be easier for the individual to interpret the pain sensation. The impact was the client would be ready to take actions to eliminate the pain (Potter and Perry, 2006). Range of motion and deep breathing exercise combination therapy has been shown to significantly reduce pain levels compared to those who were only given standard therapy in post orthopedic patients at Dr. Soetomo Hospital, Surabaya. Therefore, this therapy can be used as a complementary therapy that helped the process of wound healing and recovery of the general condition of post-orthopedic surgery patients.

This was in accordance with Nurdin et al. (2013) who also showed that deep breathing exercise was effecttive in reducing pain in postoperative orthopedic patients with severe pain scale. This proved that the reduction in pain level in the intervention group who received relaxation therapy was greater than the control group 
who only received standard ketorolac therapy $30 \mathrm{mg}$ of intravenous ampoule preparation. A greater reduction in pain in the intervention group compared to the control group was caused by an increase in endorphins in the intervention group. Range of motion and deep breathing combination therapy exercises combined the range of motion therapy with deep breathing relaxation technique.

Range of motion can lead to positive perception. Positive perceptions that affected the amygdala would be forwarded to the hypothalamus to produce Corticotropin Releasing Factor (CRF). Furthermore, CRF stimulated the pituitary gland (hypophise) to secrete endorphins as neurotransmitters that affect the mood to relax. The effect of relaxation obtained from doing range of motion was strengthened by deep breathing exercise. If people did the DBE correctly, it would reduce oxygen consumption, respiratory frequency, heart frequency and muscle tension. This would help the body to be at a high concentration so that it would activate alpha waves in the brain. Buyukyilmaz and Asti (2013) stated that these alpha waves can stimulate the release of $\beta$-endorphins and serotonin which have a role in the analgesia. $\beta$-endophine system had a high affinity for the $\mu$ opioid receptor. Opioid receptors were related to $\mathrm{G}$ proteins, which were proteins found on the cytoplasmic surface of the plasma membrane. $\mathrm{G}$ protein was activated by an increase in cAMP (cyclic adenosine monophosphate), Ca2 + (calcium), or phosphoinositid ions. The bond between opioid receptors and $\mathrm{G}$ proteins, specifically the $\mathrm{Gi}$ protein, caused a decrease in the enzyme adenylatecyclase, an enzyme that converted ATP (adenosine triphosphate) to cAMP, resulting in a decrease in cAMP. The decrease in cAMP caused a reduction in membrane permeability to ions. Opioids including $\beta$-endorphins have a direct effect on neurons, namely: (1) closing the gate $\mathrm{Ca} 2+$ at the presynaptic nerve end, so that the infusion of $\mathrm{Ca} 2+$ decreased, thereby reducing the release of pain transmitters such as glutamate, acetylcholine, norepinephrine, and substance P; and (2) caused hyperpolarization of the neurons, thus inhibiting postsynaptic neurons by opening the gate of $\mathrm{K}+$ (potassium) ions, causing $\mathrm{K}$ + influx. Receptors $\mu, \delta$, and $\kappa$ reduce the release of transmitters from the end of the presinaps, whereas the $\mu$ receptor also caused hyperpolarization at the postsynaptic end.

The combination of range of motion therapy and deep breathing exercise can manipulate the pain mechanism in the modulation process where there was an interaction between the endogenous analgesic system and the intake of pain that enter the posterior body so that pain intake can be suppressed. Range of motion and deep breathing exercise combination therapy modulated pain at the spinal level in afferent arrangements. At this level, the modulation target in the gelatinose substance in order to provide inhibition to the transmission of pain impulses. In accordance with gate control theory, combination of range of motion and deep breathing exercise therapy can stimulate many endorphins that inhibit the release of substances released by delta-A and $\mathrm{C}$ neurons that perceive the pain so that the dominant input came from beta-A fibers which would close the defense mechanism (gate). So the message conveyed in the cortex was modulation stimulation and it can decrease the pain (Potter and Perry, 2006).

Changes in perceptions that have not been formed can be caused by several factors. Rustianawati (2013) stated that there were two factors that influence perceptions, namely internal factors and 
external factors. Internal factors were factors that originate from the individual itself which can influence emotional intelligence. These internal factors came from two things, physical (individual health) and psychological (experience, feeling, ability to think and motivation). External factors can be in the form of stimulus and environment. In order to be perceived, the stimulus must be strong and exceed the stimulus threshold. Special environments or situations underlying the stimulus would also influence the perception.

With the results of this study, the side effects of analgesic use can also be reduced because patients can be recommended to reduce the dose of analgesic consumption. This would help in reducing patient costs and increasing patient satisfaction with nursing services. Giving analgesics was a standard procedure in post orthopedic surgery. The use of analgesics to treat postoperative pain was the protocol (Kneale and Davis, 2011). The temporary effect of administering pain relief would lead to many side effects such as sedation, confuse, agitation, increased production of gastrointestinal acids which actually inhibit the process wound healing, ambulation up to prolonged length of stay which greatly affected the effective cost management of patients.

Based on the result of this study, it can be concluded thatcombination therapy of Range of Motion and Deep Breathing Exercise can reduce pain in patients after orthopedic surgery. The reduction in pain in patients who received analgesic therapy (ketoleorolak) along with a combination of therapeutic range of motion and breathing exercise was greater and more significant compared to patients who only got analgesic therapy (ketorolac).

\section{REFERENCES \\ American Academy Orthopaedic Surgeons (2013). Distal Radius Fracture (Broken wrist), Diaksesdari http://- orthoinfo.aaos.org/PDFs/Aoo412.pdf \\ Ani F (2010). Efektifitas terapi musik ter- hadap penurunan nyeri post operasi pada anak usia sekolah di RSUP Haji Adam Malik Medan. Skripsi. Faculty of Nurses: Universitas Sumatera Utara.}

Basic Health Research/ RISKESDAS (2013). Riset Kesehatan Dasar 2013. Kementerian Republik Indonesia. http://www.depkes.go.id/resources/d ownload/general/Hasil\%2oRiskesdas \%202013.pdf

Chelly JE, Ben-David B, Williams BA, Kentor ML (2003). Anesthesia and postoperative analgesia: outcomes following orthopedic surgery. Orthopedics. 26(8): s865-71.

Flor H, Turk DC (2011). Chronic Pain: An Integrated Biobehavioral Approach. ISBN: 978-0-931092-90-9.

Ilmiasih R (2013). Nonpharmacological pain management promotion by family to the post surgery patients in BCH Ward of RSUPN Dr. Ciptomangun Kusumo Jakarta. Jurnal Keperawatan. 4(2): 116 - 121. https://doi.org/10.22219/jk.v4i2.2361

Indonesian Ministry of Health/Kemenkes RI (2015). Riset Kesehatan Dasar. Jakarta: Kemenkes RI.

Kneale J, Davis P (2011). Keperawatan ortopedik dan trauma. Jakarta. EGC

Lim YC, Yobas P, Chen HC (2014). Efficacy of relaxation intervention on pain, self-efficacy, and stress-related variables in patients following total knee replacement surgery. Pain Manag Nurs. 15(4):888-96. doi: 10.1016/j.p$\mathrm{mn} .2014 .02 .001$ 
National Clinical Effectiveness Committee (2013). National Early Warning Score. National Clinical Guideline No. 1. ISSN 2009-6259. https://health.gov.ie/wp-content/uploads/2015/o1/NEWSFull-ReportAugust2014.pdf

Noorisa R, Apriliwati D, Aziz A, Bayusentono B (2017). The characteristic of patients with femoral fracture in department of orthopaedic and traumatology RSU Dr. Soetomo Surabaya 2013-2016. Journal of Orthopaedi \& Traumatology Surabaya. 6(1): 1-11.

Novita D (2012). Pengaruh terapi music terhadap nyeri post operasi open reduction and internal fixation (ORIF) di RSUD DR.H. Abdul Moeloek Propinsi Lampung. Skripsi. Faculty of Health Sciences, Universitas Indonesia.

Nurdin S, Kiling M, Rottie J (2013). Pengaruh teknik relaksasi terhadap intensitas nyeri pada pasien post operasi fraktur di ruang Irina A BLU RSUP Prof Dr. R.D Kandou Manado. Jurnal Keperawatan. 1(1): 1-6.

Potter PA, Perry AG (2006). Buku Ajar Fundamental Keperawatan: Konsep, Proses, dan Praktik. Edisi 4. Volume
2. Alih Bahasa: Renata Komalasari, dkk. Jakarta: EGC.

Royal College of Physicians (2012). National Early Warning Score (NEWS): Standardising the assessment of acute illness severity in the NHS. Report of a working party. London: RCP.

Rustianawati (2013). Efektivitas ambulasi dini terhadap penurunan intensitas nyeri pada pasien post operasi laparatomidi RSUD Kudus. JIKK. 4(2): 1-8.

Schumacher MA, Basbaum AI, Way WL (2007). Opioid analgesics \& antagonists. In: Katzung BG, editor. Basic and Clinical Pharmacology. New York, NY: McGraw Hill. 489-510.

Smeltzer SC, Bare BG (2001). Buku Ajar Keperawatan Medikal-Bedah. Brunner \& Suddarth. Jakarta: EGC.

Smeltzer SC, Bare BG (2012). Buku ajar keperawatan medikal bedah. Brunner \& Suddarth, Volume 1 Edisi 12. Jakarta: EGC.

Smeltzer SC, Bare G, Hinkle JL, Cheever $\mathrm{KH}$ (2013). Brunner and Suddarth Textbook of Medical Surgical Nursing edisi 11. Philadelphia: Lippincot Williams \& Wilkins. 